\title{
AN EMPIRICAL ANALYSIS OF ROLE OF CORPORATE SOCIAL RESPONSIBILITY ON THE PERFORMANCE OF INDIAN BANKING INDUSTRIES (A CASE STUDY OF AXIS BANK INDIA)
}

Authors: Prof. Bimal Jaiswal ${ }^{1}$; Ms.Shrinjika Rastogi ${ }^{2}$; Richa Banerjee $^{3}$

Affiliations: Faculty of commerce, Department of Applied Economics, University of Lucknow ${ }^{1}$; Assistant Professor, Institute of Co-operative\& Corporate Management Research and training, Lucknow ${ }^{2}$;Assistant

Professor, Department of Business Administration, University of Lucknow ${ }^{3}$. E-mail:bimalsiyaram@yahoo.com ${ }^{1}$; shrinjika.rastogi@gmail.com ${ }^{2}$ richa.banrj@gmail.com ${ }^{3}$

$$
\underline{\text { DOI }<10.26821 / I J S R C .7 .1 .2019 .7113>~}
$$

\begin{abstract}
In today's world corporate social responsibility has become an important task for every organization as it not only depicts organization's ethical behavior but also shows the financial progress of the organization. In developing country like India the banking sector plays a major role in providing funds for development and growth of the economy. In India, Axis Bank Foundation has been recognized as the outstanding corporate foundation by Forbes India. The purpose of this paper is to study the relationship between Axis Bank's CSR expenditure and its performance and this study will also provide information regarding the Axis bank's activities under its Corporate Social Responsibility program. The research methodology involves application of Pearson's correlation to conduct the statistical investigation among different parameters of the study. The study provides significant managerial allusion for strategy making and for improving firm's performance by establishing connect between the CSR expenditure and firm performance.
\end{abstract}

Key Words: Banking Performance, Axis Bank, Net Profit, Expenditure, Return On equity, Return on assets.

\section{Introduction}

Corporate social responsibility (CSR) is a business approach that contributes to sustainable development by delivering economic, social and environmental benefits for all stakeholders. CSR of an organization refers to what an organization does on a voluntary and nonprofit basis for the welfare of the society. Peter F.Drucker states that, Business should develop concern for society and peruse welfare activities which should form an important area of operation. It is a demand, that quality of life becomes the business of businesses. The new demand for business is to make social values and benefits, create freedom for individuals and all together a good society.

The Corporate social responsibility (CSR) in Indian banking sector is directed toward to achieve financial inclusion by supplying banking and other financial services to the economically backward areas of the country. in this Axis Bank has made its contribution through its Corporate social responsibility (CSR) policy its primary aim is to make useful and measureable impact on the life's of socially, psychologically and economically challenged people through its integrated approach of development which aims at creating sustainable livelihood and creating awareness amongst public at large on public issues. 


\section{Literature Review}

While there are many research papers which have tested the relationship between CSR and banking performance and the result of these studies are different from each other because CSR can vary from business to business and also according to social needs of time and society (Amran etal,2013). All the organization have different type of responsibility such as: Social, legal and economical etc.

S.SinghalH.Bhagtani(2017) analyze the degree and direction of association between corporate governance, CSR and firm performance. In the result they found a positive correlation between CSR and firm performance.

Fiori.G, F.Di.Donato and Izzo,M.F,(2007) analye the impact of voluntary discloser of Corporate social responsibility (CSR) on firms stock prices of Italien Listed companies and in the result they found that firm stock price are not affected by the CSR report.

Kelin and Dawar(2004) proposed that Corporate social responsibility (CSR) has value for the firm as a form of insurance policy against the negative events of the organization.

World Business council for Sustainable Development (2001), Mention that Corporate social responsibility (CSR) can support the management by making it more committed toward business and towards the sustainable development of the society.

Philip L.Cochran,Robert A. Wood(1984) examined the relation between Corporate social responsibility (CSR) and Financial performance and in the result they found that Average age of corporate assets are highly correlated with the social responsibility ranking.

Davis,keith(1973) Defines Corporate social responsibility (CSR) as, a firm's responsibility towards various issues and challenges can be revolve around legal and economical needs of the organization.

\section{Objective}

- To study Corporate social responsibility (CSR) expenditure by Axis Bank in last 3 years and activities undertaken under Corporate social responsibility.

- To study the relationship between corporate social responsibility (CSR) expenditure and Axis Bank performance.

\section{About Axis Bank CSR Expenditure}

- Axis bank carries its corporate social responsibility (CSR) expenditure through its in house Axis Bank Foundation.

- Axis Bank Foundation is the corporate social responsibility (CSR) arm of Axis Bank. it was formed in 2006 with the aim of focus and structure to banks corporate social responsibility and corporate citizenship agenda.

- Axis Bank Foundation has been recognized as the outstanding corporate foundation for the year2014 by Forbes India.

- The foundation mandate is to enhance economic inclusion for those living on the fringe of poverty.

- Axis Bank Foundation is governed by a board comprising of member who are from the development sector and business leaders.

- The foundation is managed by a team comprising of people with development and corporate sector expertise.

- These inclusion communities heavily dependent on the natural resources and hand skills for their livelihood.

- Foundation work in partnership with NGO to design and deliver its programs. 
- The programs are based on framework that comprise of :

1. Need of community

2. Build and strengthen the capacity of communities to work towered their development goals.

3. Linkages with financial institutions and markets. The programs outcomes are also aligned to achieve some of the Sustainable Development Goals (SGD's) set by the united nations 2015

GOAL1: No Poverty

GOAL2: Zero Hunger

GOAL4: Quality Education

GOAL5: Gender Equality

GOAL10: Reduce Income Inequality

GOAL 13: Climate Action.

\section{Research Methodology}

It includes collection of data and its analysis is followed by its interpretation. The present research paper only based on Secondary Data available through various sources and thus research methodology comprises of:

1. Collection of data, 2.Data analysis and interpretation

\section{Assumption:}

- As per norms average Net Profit of the bank for past three years should go for CSR expenditure and therefore it has been assumed that Axis bank must have allocated around 2\% of average Net profit towards the Corporate social responsibility (CSR) expenditure regarding complains of set norms.

- The firm's performance is measured through Return on Assets (ROA) and Return on Equity (ROE).

\section{Variables}

The present research incorporated with 3 types of variables i.e. dependent variables, independent variables, and control variables. The two variables which are showing firm performance is Return on assets, Return on equity are taken as dependent variables. The control variables include Earning per share, Board size, board meeting and other factors which can also affect the CSR and banking performance. Expenditure on corporate social responsibility is taken as independent variable. The expenditure on corporate social responsibility of Axis Bank comprise of expenditure made by the bank on health and medical care, education , poverty alleviation programmers etc.

Return on Assets shows profit of an organization in relation to its total assets; here, data of return on assets of Axis Bank is taken from the period2008-09 to 2015-2016.

Return on equity measures profitability of an organization in relation to shareholders equity. Data of return on equity of Axis bank is taken from the period2008-09 to 2015-2016.

Net profit of Axis Bank is taken from its annual report for the period of 10 years i.e. from 2008-09 to 2015-2016 


\section{Analysis \& Interpretation:}

Table: 1; Corporate social responsibility (CSR) Expenditure and Activities of Axis Bank

\begin{tabular}{|l|l|l|l|l|l|l|}
\hline years & $\begin{array}{l}\text { Average } \\
\text { Net } \\
\text { Profit of } \\
\text { the } \\
\text { company } \\
\text { for last 3 } \\
\text { years }\end{array}$ & $\begin{array}{l}\text { Prescribed } \\
\text { CSR } \\
\text { Expenditure }\end{array}$ & $\begin{array}{l}\text { Total amount } \\
\text { spent in } \\
\text { Financial in } \\
\text { Year(excluding } \\
\text { administrative } \\
\text { expenses) }\end{array}$ & $\begin{array}{l}\text { of } \\
\text { amount } \\
\text { spent. }\end{array}$ & $\begin{array}{l}\text { Amount } \\
\text { unspent }\end{array}$ & $\begin{array}{l}\text { of } \\
\text { amount } \\
\text { unspent }\end{array}$ \\
\hline $\begin{array}{l}2016- \\
17\end{array}$ & 9821.75 & 196.44 & 135.39 & $68.92 \%$ & 61.5 & $31.31 \%$ \\
\hline $\begin{array}{l}2015- \\
16\end{array}$ & $\mathbf{8 1 5 1 . 3 4}$ & 163.03 & 137.41 & $84.29 \%$ & 25.62 & $15.71 \%$ \\
\hline $\begin{array}{l}2014- \\
15\end{array}$ & 6688.67 & 133.77 & 123.22 & $92.11 \%$ & 10.55 & $7.89 \%$ \\
\hline
\end{tabular}

From the year 2014 to 2016 the amount spent on corporate social responsibility is continually going down that means amount unspent is increasing as much as to $30 \%$ of total allocated amount this is an alarming situation for the government as banks are spending less on social development.

Table: 2; Manner in which amount is spent during the financial year

\begin{tabular}{|c|c|c|c|c|c|c|}
\hline Activities & 2016-17 & $\begin{array}{l}\% \\
\text { amou } \\
\text { amou } \\
\text { spent }\end{array}$ & $2015-16$ & $\begin{array}{ll}\% & \text { of } \\
\text { amount } & \text { of } \\
\text { amount } & \\
\text { spent } & \end{array}$ & 2014-15 & $\begin{array}{l}\% \\
\text { amount }\end{array}$ \\
\hline $\begin{array}{l}\text { Contribution to } \\
\text { Axis banks } \\
\text { foundation and } \\
\text { NGO's towards } \\
\text { undertaking CSR } \\
\text { activities }\end{array}$ & 82.24 & & 73.58 & 54.22 & 62.18 & 51.22 \\
\hline $\begin{array}{l}\text { Financial literacy } \\
\text { and inclusion and } \\
\text { public awareness } \\
\text { programs }\end{array}$ & 32.21 & 23.78 & 30.03 & 22.13 & 52.32 & 43.10 \\
\hline $\begin{array}{l}\text { Environmental } \\
\text { sustainability } \\
\text { programs }\end{array}$ & 13.24 & 9.77 & 28.35 & 20.89 & 5.75 & 4.74 \\
\hline $\begin{array}{ll}\text { MSME } & \text { sector } \\
\text { building } & \\
\text { programs } & \end{array}$ & 2.50 & 1.85 & 1.67 & 1.23 & 1.09 & 0.90 \\
\hline $\begin{array}{l}\text { Education and } \\
\text { Skill building } \\
\text { programs }\end{array}$ & 5.28 & 3.90 & 2.08 & 1.53 & 0.06 & 0.05 \\
\hline Total & 135.47 & 100.00 & 135.71 & 100.00 & 121.40 & 100.00 \\
\hline
\end{tabular}

The above table shows that axis bank is spending the highest amount on Axis banks foundation and NGO's followed 
by Financial literacy and inclusion and public awareness programs, Environmental sustainability programs, MSME sector building programs and lastly on Education and Skill building programs.

\section{Relationship between Corporate social responsibility (CSR) Expenditure and bank performance of Axis bank}

Corporate social responsibility expenditure is the expenditure on activities related to societal development. As per government norm the quantum of corporate social responsibility expenditure should be $2 \%$ of reported average net profit. Accordingly we have calculated corporate social responsibility expenditure from the year 2008-09 to 2015-2016 as given in below mention table.

The bank performance is measured through return on equity and return on assets. Both these measures are taken from annual report of axis bank from year 2008-09 to 2015-2016 as given in below mention table.

To calculate the relationship between CSR Expenditure and bank performances of Axis bank correlation coefficient has been calculated using MS Excel worksheet

Table: 3; Statement of correlation between Return on Equity (ROE) and Corporate social responsibility (CSR) expenditure

\begin{tabular}{|l|l|l|l|l|l|l|l|l|}
\hline & 2008-09 & $\mathbf{2 0 0 9 - 1 0}$ & $\mathbf{2 0 1 0 - 1 1}$ & $\mathbf{2 0 1 1 - 1 2}$ & $\mathbf{2 0 1 2 - 1 3}$ & $\mathbf{2 0 1 3 - 1 4}$ & $\mathbf{2 0 1 4 - 1 5}$ & $\mathbf{2 0 1 5 - 1 6}$ \\
\hline $\begin{array}{l}\text { RETURN } \\
\text { ON Equity }\end{array}$ & $19.93 \%$ & $19.89 \%$ & $20.13 \%$ & $21.22 \%$ & $20.15 \%$ & $18.23 \%$ & $18.57 \%$ & $17.46 \%$ \\
\hline $\begin{array}{l}\text { NET } \\
\text { PROFIT (Rs } \\
\text { in CR) }\end{array}$ & 1851.36 & 2514.53 & 3388.49 & 4242.21 & 5179.43 & 6218.00 & 7358.00 & 8224.00 \\
\hline $\begin{array}{l}\text { Avg NET } \\
\text { PROFIT(Rs } \\
\text { in CR) }\end{array}$ & 2345.17 & 3760.53 & 5495.55 & 7317.59 & 9357.67 & 11494.31 & 13850.10 & 16317.33 \\
\hline $\begin{array}{l}\text { CSR (Rs in } \\
\text { Cr) }\end{array}$ & 46.90 & 75.21 & 109.91 & 146.35 & 187.15 & 229.88 & 277.00 & 326.34 \\
\hline
\end{tabular}

\section{Correlation Between ROE and CSR expenditure}

$$
-0.76118
$$

\section{Interpretation:}

There is a strong correlation (i.e. - 0.76) between ROE and CSR expenditure. The negative sign is due to Equity being cash inflow where as CSR being cash outflow.

Table: 4; Statement of correlation between Return on Assets (ROA) and Corporate social responsibility (CSR) $\underline{\text { expenditure }}$

\begin{tabular}{|c|c|c|c|c|c|c|c|c|}
\hline & $\begin{array}{l}2008- \\
09\end{array}$ & $\begin{array}{l}2009- \\
10\end{array}$ & $\begin{array}{l}2010- \\
11\end{array}$ & $\begin{array}{l}2011- \\
12\end{array}$ & $\begin{array}{l}2012- \\
13\end{array}$ & $\begin{array}{l}2013- \\
14\end{array}$ & $\begin{array}{l}2014- \\
15\end{array}$ & $2015-16$ \\
\hline $\begin{array}{ll}\text { RETURN } & \text { ON } \\
\text { ASSETS } & \end{array}$ & $1.44 \%$ & $1.67 \%$ & $1.68 \%$ & $1.68 \%$ & $1.70 \%$ & $1.78 \%$ & $1.83 \%$ & $1.72 \%$ \\
\hline $\begin{array}{l}\text { NET PROFIT (Rs in } \\
\text { CR) }\end{array}$ & 1851.36 & 2514.53 & 3388.49 & 4242.21 & 5179.43 & 6218.00 & 7358.00 & 8224.00 \\
\hline Avg of NET PROFIT & 2345.17 & 3760.53 & 5495.55 & 7317.59 & 9357.67 & 11494.3 & 13850.1 & 16317.33 \\
\hline CSR (RS in Cr) & 46.9 & 75.21 & 109.91 & 146.35 & 187.15 & 229.88 & 277 & 326.34 \\
\hline \multicolumn{5}{|c|}{ Correlation Between ROA and CSR expenditure } & & 0.74547 & & \\
\hline
\end{tabular}

\section{Interpretation}


There is a positive and strong correlation (i.e. 0.74) between ROA and CSR expenditure. This shows that CSR expenditure is not only for the welfare of society but also improves quality of business in terms of Return on Assets.

\section{Conclusion}

From the above study it has been concluded that:

- The CSR initiative has a strong bearing on firms performance measured in terms of Return on Equity(ROE) and Return on Assets(ROA)

- There is a strong correlation between Return on Equity (ROE) Vs.CSR expenditure as well as Return on Assets (ROA) Vs. CSR expenditure.

- The entire study is based on secondary data taken from annual report of Axis Bank starting from 2008-09 to 2015-16.

- Reserve Bank of India (RBI), Ministry of Corporate affairs (MCA) and Security Exchange Board of India (SEBI) issues guideline from time to time for very businesses to follow all the rules and regulations.

- There are special guidelines for corporate social responsibility bill 2013 which are applicable from 2014-15.

- RBI set up Khan Committee in 2005 and Nachiket committee in 2013 to cover all the commercial bank under financial inclusion plan and make it compulsory to submit report on CSR activities at the end of every financial year.

- But still more regulation and new policies are required to implement the concept of CSR in Indian Banking Sector.

\section{Limitations}

The study is based on secondary data which is taken from annual report (Any manipulation and window dressing will leads to misleading analysis)

\section{Scope for future research}

- The study gives a clear picture of đegree and direction of CSR and firm performance.

- Any additional research can do on the association between these parameters with respect to other industries.

- Also the scope of current research can be widened by expanding the time period and a comparative study may be conducted between different banks.

\section{Reference}

[1]. Amran,A.,Zain,M.M.,Sulaiman,M.,Sarker,T.,\&Ooi,S.K.(2013).Empowering society for better corporate social responsibility(csr):the case of Malaysia .Kajian Malaysia,31(1),57.

[2]. Cochran,Philip L.,\&Robert A. Wood.(1984).corporate social responsibility and financial performance. Academy of Management Journal 27(1),42-56.

[3]. Davis, Keith(1973).the case for and against Business assumption of society responsibility. Academyof Management Journal,1,312-322.

[4]. Drucker, Peter F.(1984).A new look at corporate social responsibility .Mckinsey Quarterly(4),17-28.

[5]. Fiori,G.,Di Donato F.,\&Izzo,M.F.(2007).corporate social responsibility and stock prices: an analysis on Italian listed companies. Paper presented at the $4^{\text {th }}$ conference of performance measurement and management control, Nizza, September, 26-28.

[6]. H.Singhal,Shuchi\&Bhatani(2017).A study of relationship between corporate governance, CSR and firm performance: empirical evidence from Indian banking industry . Amity Business Journal6(2),30-34.

[7]. Kelin,Jil and Niraj Dawar(2004).Corporate social responsibility and consumers, Attribution and Brand evaluation 
in product-harm crisis. International Journal of Research in Marketing 21(3),203-217.

[8]. Mouly Potluri,R., Batima,Y.,\&Madiyar, k.(2010).Corporate social reasonability: A study of Kazakhstan corporate sector. Social responsibility Journal, 6(1), 33-44.

[9]. Velnampy,T.(2013).Corporate governance and firm performance: A study of Sri Lanka Manufacturing Companies.

[10]. WBCSD/WRI (World Business council for sustainable Development/World Resource Institute).(2001).

[11]. Wu,M.W.,\&Shen,C.H(2013).Corporate social responsibility in banking industry: Motive and financial performance. Journal of Banking and Finance,37(9),3259-3547.

[12]. Axis Bank Foundation.WWW.axisbankfoundation.org 